\title{
The role and importance of social capital in rural development
}

\author{
Svetlana Podgorskaya ${ }^{1, *}$ and Sergei Schitov ${ }^{1}$ \\ ${ }^{1}$ Federal Rostov Agrarian Scientific Center (FRASC), Institutskaya str., 1, Rassvet village, Rostov \\ region, 346735, Russia
}

\begin{abstract}
A fundamentally new characteristic of the policy in relation to the development of rural areas is the achievement of a high standard of living of the rural population due to non-material factors of development, namely, the quality of the social environment and the state of the environment. In the new model of rural development, the main element is social capital and the level of development of rural social networks based on Internet technologies. Digitalization contributes to the active involvement of the rural population of Russia in network social interaction. Social networks are more important for rural residents than for urban residents, since they neutralize the territorial disunity of villages and provide access to information. They become a structural component of social capital, a condition and factor of its formation and reproduction. However, the level of digitalization in rural areas remains insufficient and is significantly inferior to urban areas. The development and improvement of social capital contributes to the use of hidden intangible resources, the disclosure of the potential of rural areas, the growth of its competitiveness, the formation of economic and social ties.
\end{abstract}

\section{Introduction}

The global community is increasingly discussing a new paradigm of sustainable development based on inclusive economic growth, which shifts the goals from increasing the gross domestic product to the concept of human well-being in a broad sense [1,2].

According to G. D. Ploeg, T. Marsden, and others, "social capital should be understood in a broader context, as the ability of individuals, groups, organizations, and institutions to collaborate and use social relationships to achieve common goals and gain common benefits".

In the works of A. Konkov, M. Mezentsev, D. Merkulov, V. Radaev, S. Sysoev, N. Tikhonova, social capital is considered as access to resources and reduction of transaction costs.

The issues of studying the role of social networks in the formation of social capital and the development of society are presented in the works of A. Artimovich, P. Barth, S. Borghetti, M. Ignatov, N. Lin, V. Pechenkin, V. Puzikov, A. Churakov, L. Chernyak, and others.

\footnotetext{
*Corresponding author: svetlana.podgorskaya@gmail.com
} 
Russian scientists T. Alishev, D. Bespartochny, A. Larina, V. Rukavishnikov and others study various aspects of social trust in Russian society.

Various aspects of the new civilizational approach to the development and management of rural areas are presented in the works of foreign and domestic scientists: M. AmbrosioAlbalá, J. Bastiaensen, L. Sullivan, L. Ryser, G. Halseth [3], E. Guinjoan, A. Badia, A. F. Tulla [4], B. Nilsson, A. S. Lundgren [5], E. Pisani, S. Micheletti [6], A. Kostyaev [7] and others [8].

One of the central points in the new paradigm of rural development is the concept of social capital. If human capital is long enough in the field of view of Russian scientists, publications on the social capital of rural areas have appeared recently [9, 10, 13, 17, 23].

However, a review of the scientific literature on this subject has shown that underresearched issues of the formation and reproduction of social capital in terms of a new model of rural development.

\section{Materials and Methods}

The statistical base of the research was made up of official data of the State statistics of the Russian Federation and reports of the Ministry of Agriculture, published results of surveys of rural residents of Russian regions, and the works of domestic and foreign scientists. The methodological basis of the research is a systematic approach, according to which rural areas are considered as a complex system, the determinant of the development of which is social capital. In the course of the research, general scientific methods were used: analysis and synthesis; induction, deduction and analogy; abstraction; generalization; statistical and economic analysis.

\section{Results}

The category of social capital as a source of benefits through the interaction of a group of people was introduced into scientific circulation in 1980 by the French sociologist Pierre Bourdieu. The value of this resource is the reduction of transaction costs due to social integration and the creation of a reference environment.

The social capital of rural territories implements the following main functions:

- economic through increasing material resources and increasing the competitiveness of the rural economy;

- formation of civil society through the development of democracy and political participation;

- promotion of self-realization of the individual by providing favorable conditions for achieving their goals and unlocking their potential;

- socialization through integration into the system of rural society, the acquisition and adoption of its social norms, rules and values;

- ensuring the stability and cohesion of the rural social system on the basis of establishing relationships of trust, economic and social ties.

The main factors in the formation and reproduction of social capital in rural areas are various social groups organized by professional, confessional, ethnic, kinship and other categories; the state, municipal authorities and local self-government bodies; non-profit organizations and public associations, virtual network communities.

Various aspects of the influence of social capital on economic growth are established and empirically proved in the studies of foreign and domestic scientists [11, 12, 13, 14]. Russian scientists N. Lebedev and O. Lomovtseva revealed the dependence of the economic development of subjects of the southern Federal district of the Russian 
Federation on the level of development of social capital territories, G. Brazhnik determines the impact of social capital on social and economic activities of the municipality through the mechanisms of social partnership and network communication.

Using the example of the municipality of the Republic of Tatarstan, A. Shakirova and T. Kramin empirically proved the influence of social capital on economic growth. The independent variable was the indicator of the number of organizations in the district that use the Internet and e-mail, the dependent variable was the gross territorial product.

The work [15] investigated the causal relationship between the level of social capital and the development of the microfinance system in rural areas.

The influence of the development of rural social capital on the activities of small enterprises in the territory of the municipality is established [16].

The most important characteristics of social capital are the level of trust and involvement in networking (Figure 1). It is proved that the rural population with a wide circle of trust has a higher social activity, it can be support for the initiatives by the public and local authorities [17].

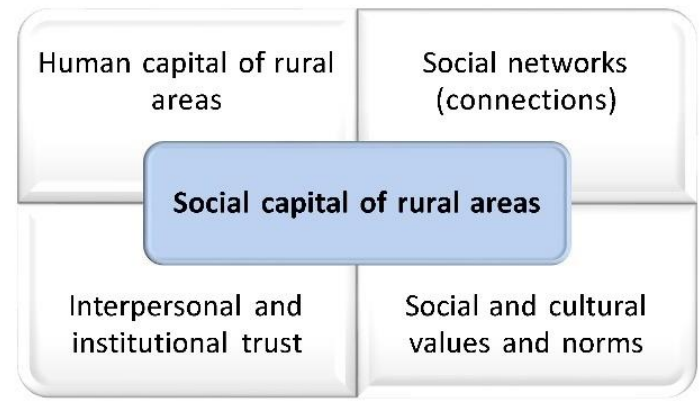

Fig. 1. Structure of social capital in rural areas. Note: Developed by the authors.

Trust ensures the strength of social ties and contributes to the creation of common values and norms. The development of social networks makes it possible to use the resources of this network to achieve goals, including solving economic issues, and promotes the spread of innovations [18].

Social capital of rural population in the sustainable development of rural areas will be considered from the perspective of inclusion in the network of social relations, which is formed on the basis of norms of trust to generate beneficial effects in the development of socio-ecological - economic sectors of the village.

F. Fukuyama highlights trust as a factor in economic growth. It determines progress, ensures an increase in the efficiency of the economy by reducing costs. S. Nek and Z. Keefer [Knack, Keefer, 1997] found that with an increase in the level of confidence in the country by one percentage point, economic growth increases by more than $0.5 \%$.

At the same time, a study of the involvement of the rural population in the practice of civic participation showed that almost a third of the villagers (32\% of respondents) noted that today no one can be trusted, which is an extreme degree of distrust in society, while only $27 \%$ of citizens agreed with this position [19].

Today, there is no well-established methodology for measuring social capital, either in foreign or domestic science. The assessment of social capital is based mainly on the method of questioning rural residents.

For example, a survey of residents of municipal districts of the Vologda Oblast showed that the social capital of these territories is very limited, residents have a low level of institutional trust, weak civic activity, and the population is focused on survival rather than development [17]. 
The same conclusions are confirmed by the authors research [20]. In their responses, respondents (rural residents of the Rostov region) showed disinterest in personal participation in solving the problems of their settlements. Changes in improving the quality of life in rural areas are primarily associated with the actions of the local administration, regional and federal governments. Only on preserving ecology in their territories a majority of respondents said personal responsibility and an important role of initiative villagers.

Today, in the era of digitalization of all spheres of society, the development of network interaction of the rural population on the basis of modern information technologies and means of communication for the development of rural areas is of interest. Modern technologies allow us to overcome some isolation of rural settlements due to their territorial remoteness [21,22], contribute to the inter-district consolidation of the population by areas of interest, organizational activities for initiating and managing projects, etc.

The strength of connections within and between networks directly depends on the level of trust, both interpersonal and institutional [23].

It should be noted that the development of local Internet communities is particularly important, since their participants are residents of a certain locality (settlement, district) and the focus of their interaction is concentrated within this locality. Their role consists in the ability to self-organize and get the latest information, advanced technologies, and qualified consulting assistance for the implementation of initiative projects. The development of this form of interaction is determined by the level of informatization - access to high-quality and sustainable Internet and mobile communications in rural areas. However, today there is a digital divide in the level of provision of these services in urban and rural areas, contributing to a gap not only in the development of rural networking, but also in the availability of information and knowledge.

The federal target program "Elimination of Digital Inequality" has now been transformed into the National Project "Digital Economy of the Russian Federation". Despite the successful implementation of these projects, there is still a low availability of digital communications for the rural population, which is expressed not only in the quality and availability of technological infrastructure, but also in the level of digital competencies of users and digital literacy of the rural population. Thus, in 2018, the digital literacy index of the rural population of the Russian Federation was estimated at 55\% versus 59\% for the urban population.

The possibilities of rural residents to use technical means to access information are presented in table 1 .

Table 1. Provision of the population with personal computers and Internet access. Note: Compiled by the authors on the basis of Federal State Statistic Service data.

\begin{tabular}{|c|c|c|c|}
\hline Place of residence & 2016 & 2017 & 2018 \\
\hline \multicolumn{4}{|c|}{$\begin{array}{l}\text { Households with personal computers. by type of location and household composition } \\
\text { (as a percentage of the total number of households) }\end{array}$} \\
\hline Urban area & 78.4 & 78.3 & 76.2 \\
\hline Rural area & 61.7 & 62.6 & 60.5 \\
\hline \multicolumn{4}{|c|}{$\begin{array}{l}\text { Households with Internet access. by type of location and household composition } \\
\text { (as a percentage of the total number of households) }\end{array}$} \\
\hline Urban area & 78.5 & 79.5 & 79.7 \\
\hline Rural area & 63.6 & 66.5 & 67.1 \\
\hline
\end{tabular}

Households in rural areas provided with access to the Internet in less than urban residents. If in 2018 , almost $80 \%$ of residents in urban areas have access to the Internet, 
then only $67 \%$ in rural areas, which makes it much more difficult to disseminate information.

Among the reasons for not using the Internet in rural areas, "No need" is most often mentioned (48\%) (Figure 2), which indicates the lack of interest of the population in obtaining operational information.

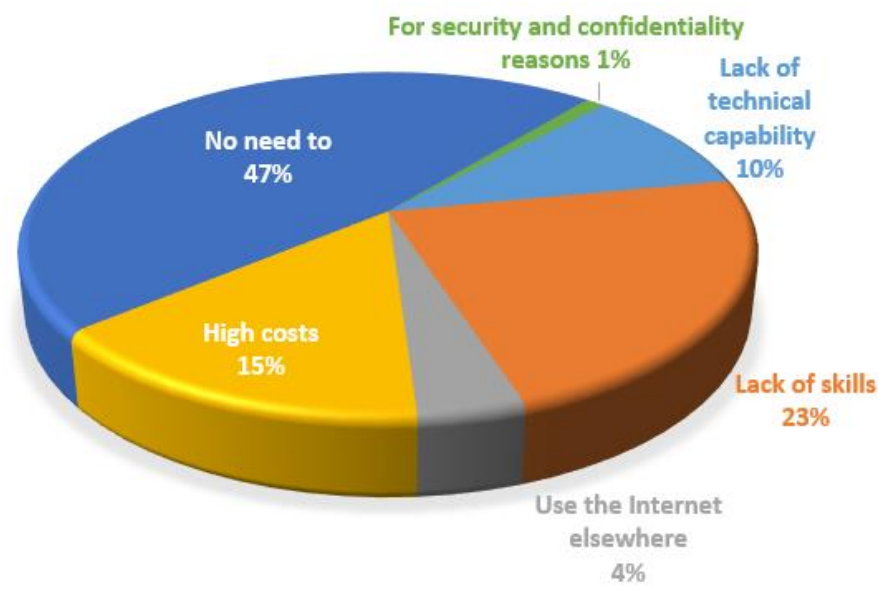

Fig. 2. Reasons for non-use of the Internet by households in rural areas who do not have access to the Internet in 2018. Note: Compiled by the authors on the basis of Federal State Statistic Service data.

The next most important reason for refusal is "Lack of skills" and accounts for $23 \%$ of those who do not have access to the Internet.

Having considered the types of devices that are used to access the Internet, it becomes obvious that the urban population is technically better equipped than the villagers (Table 2).

Table 2. Distribution of households by type of devices used to access the Internet, in urban and rural areas (as a percentage of the total number of households). Note: Compiled by the authors on the basis of Federal State Statistic Service data.

\begin{tabular}{|l|c|c|c|c|c|c|}
\hline \multirow{2}{*}{ Type of device } & \multicolumn{3}{c|}{ Urban area } & \multicolumn{3}{c|}{ Rural area } \\
\cline { 2 - 7 } & $\mathbf{2 0 1 6}$ & $\mathbf{2 0 1 7}$ & $\mathbf{2 0 1 8}$ & $\mathbf{2 0 1 6}$ & $\mathbf{2 0 1 7}$ & $\mathbf{2 0 1 8}$ \\
\hline Personal computers (total) & 74.9 & 74.8 & 73.4 & 56.2 & 56.3 & 55.4 \\
\hline $\begin{array}{l}\text { Including: } \\
\text { desktop (stationary) computers }\end{array}$ & 45.6 & 43.6 & 42.7 & 32.8 & 31.5 & 31.4 \\
\hline $\begin{array}{l}\text { mobile computers (laptop. netbook. } \\
\text { ultrabook) }\end{array}$ & 42.7 & 44.2 & 42.8 & 28.3 & 29.6 & 28.3 \\
\hline tablet computers & 27.8 & 30.1 & 28.7 & 14.7 & 16.8 & 16.3 \\
\hline $\begin{array}{l}\text { Mobile devices (mobile phones or } \\
\text { smartphones. e-book readers. etc.) }\end{array}$ & 53.1 & 59.8 & 65.9 & 36.3 & 44.3 & 49.8 \\
\hline Smart TV & 6.8 & 9.1 & 10.7 & 2.6 & 4.1 & 4.9 \\
\hline Video game consoles & 2.2 & 3.3 & 3.3 & 1.0 & 1.3 & 1.1 \\
\hline
\end{tabular}

Urban residents have several devices in their arsenal to access the Internet, which allows them to constantly stay connected and receive information. Rural residents are technically worse off.

Considering the places where the population uses the Internet, it turned out that urban and rural residents have the same preferences (Table 3 ).

The majority of citizens use the Internet at home, $97 \%$ in the city and $94 \%$ in the village. Some differences in the consumption of information services depend on the specifics of the activity and the development of the communication infrastructure. This 
explains the lower percentage of rural residents who access the Internet in public or other places.

Table 3. Places where the population uses the Internet in urban and rural areas (as a percentage of the total population using the Internet). Note: Compiled by the authors on the basis of Federal State

Statistic Service data.

\begin{tabular}{|l|c|c|c|c|c|c|}
\hline \multirow{2}{*}{$\begin{array}{l}\text { Places where the Internet is } \\
\text { used }\end{array}$} & \multicolumn{3}{|c|}{ Urban area } & \multicolumn{3}{c|}{ Rural area } \\
\cline { 2 - 7 } & $\mathbf{2 0 1 6}$ & $\mathbf{2 0 1 7}$ & $\mathbf{2 0 1 8}$ & $\mathbf{2 0 1 6}$ & $\mathbf{2 0 1 7}$ & $\mathbf{2 0 1 8}$ \\
\hline At home & 96.8 & 96.9 & 97.4 & 92.8 & 94.1 & 94.2 \\
\hline At work & 37.5 & 42.8 & 45.4 & 27.3 & 32.0 & 33.8 \\
\hline $\begin{array}{l}\text { In public access points (hotels. } \\
\text { airports. cafes. etc.) }\end{array}$ & 14.2 & 21.5 & 24.6 & 5.3 & 9.8 & 9.9 \\
\hline From friends. acquaintances & 13.9 & 18.5 & 20.3 & 14.1 & 18.6 & 19.8 \\
\hline At the place of study & 9.0 & 9.7 & 9.0 & 9.0 & 9.2 & 9.0 \\
\hline In public libraries & 0.9 & 1.2 & 1.1 & 0.5 & 0.8 & 0.5 \\
\hline At the Russian Post offices & 0.4 & 0.5 & 0.7 & 0.3 & 0.8 & 1.0 \\
\hline In computer clubs & 0.7 & 0.7 & 0.6 & 0.6 & 0.6 & 0.3 \\
\hline In other places & 13.5 & 20.6 & 19.2 & 7.7 & 12.7 & 12.6 \\
\hline
\end{tabular}

The purposes for which rural residents use the Internet vary according to the needs of the population. The most popular 5 queries are shown in Figure 3.

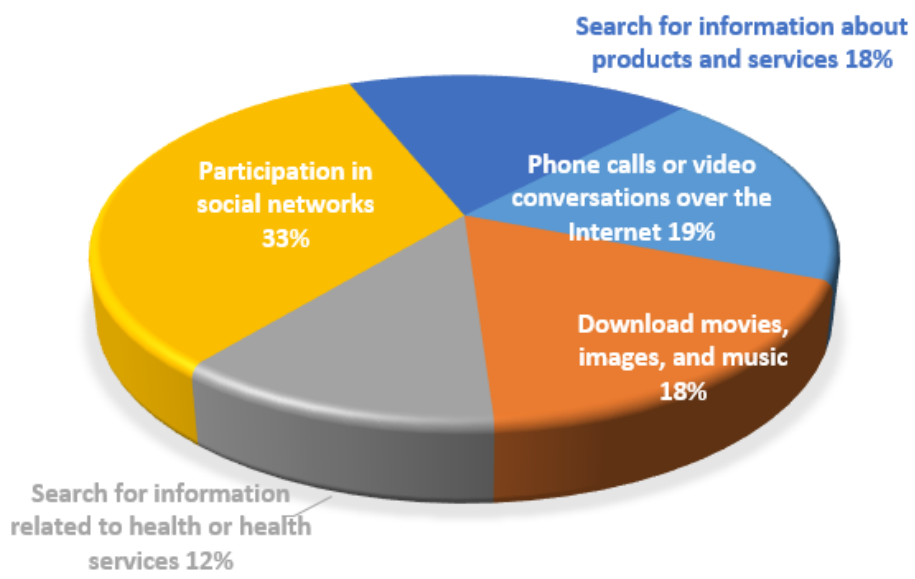

Fig. 3. Goals of using the Internet by the population in rural areas in 2018 .

Among the most "unpopular" requests are reading books, magazines, newspapers online, as well as downloading them; searching for information about cultural events and information about cultural objects; downloading computer programs; searching for advanced training courses, trainings, education; studying employment issues, vacancies; voting and consulting on political and public issues; conditions for distance learning; participation in professional networks.

Thus, the problem of communication and entertainment is compensated through the use of the Internet, self-education remains a little-demanded area among rural residents, as in urban areas, but with higher demand.

In Table 4, it is possible to assess the interaction of residents with the authorities, urban and rural populations are quite active in communicating with the authorities, and urban residents are more active precisely due to the use of the Internet.

Table 4. The population that interacts with state and local government bodies to receive services, according to the methods of interaction and the type of locality (as a percentage of the total population). Note: Compiled by the authors based on the data [24]. 


\begin{tabular}{|l|c|c|c|c|c|c|c|c|c|}
\hline & \multicolumn{3}{|c|}{ Total } & \multicolumn{3}{c|}{ Urban area } & \multicolumn{3}{c|}{ Rural area } \\
\cline { 2 - 11 } & $\mathbf{2 0 1 6}$ & $\mathbf{2 0 1 7}$ & $\mathbf{2 0 1 8}$ & $\mathbf{2 0 1 6}$ & $\mathbf{2 0 1 7}$ & $\mathbf{2 0 1 8}$ & $\mathbf{2 0 1 6}$ & $\mathbf{2 0 1 7}$ & $\mathbf{2 0 1 8}$ \\
\hline Interacted total & 56.1 & 65.7 & 72.9 & 57.6 & 68.2 & 75.3 & 51.6 & 58.3 & 65.6 \\
\hline Where: & & & & & & & & & \\
\hline $\begin{array}{l}\text { via the Internet } \\
\text { (using official } \\
\text { websites and portals } \\
\text { of state and } \\
\text { municipal services) }\end{array}$ & 28.8 & 42.3 & 54.5 & 32.1 & 46.1 & 58.3 & 18.8 & 30.6 & 43.1 \\
\hline personal visit & 22.5 & 24.0 & 21.5 & 21.6 & 24.1 & 21.6 & 25.1 & 23.8 & 21.0 \\
\hline $\begin{array}{l}\text { in the multifunctional } \\
\text { center for the } \\
\text { provision of state and } \\
\text { municipal services } \\
\text { (MFC) }\end{array}$ & 11.8 & 18.9 & 19.6 & 11.7 & 18.5 & 19.1 & 12.2 & 19.9 & 20.9 \\
\hline Did not interact & 43.9 & 34.3 & 27.1 & 42.4 & 31.8 & 24.7 & 48.4 & 41.7 & 34.4 \\
\hline
\end{tabular}

The social capital of rural areas is formed by creating local rural communities based on the principle of direct participation of residents in decision-making (Figure 4).

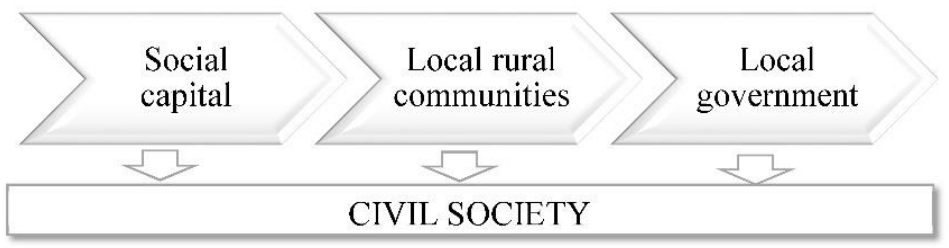

Fig. 4. Objectives of the development of social capital in rural areas. Note: Developed by the authors.

The population is included in a wide network of social relations, which intensifies the processes of self-organization and promotes the transition of local rural communities from the state of objects of management to the state of subjects of management as the basis of local self-government (Figure 5).

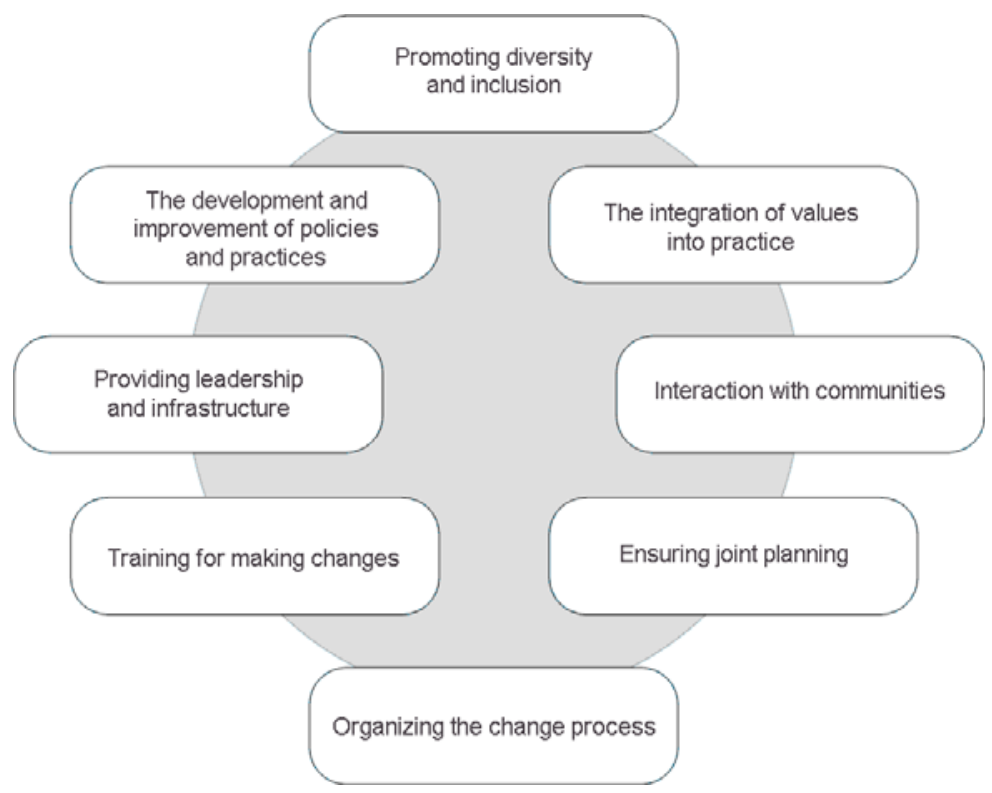

Fig. 5. Key aspects of community development activities. Note: A source [25]. 
The involvement of the rural population in the life of the community takes place in various organizational forms: clubs, associations, church groups or foundations, initiative groups, neighborhood communities, etc.

According to Federal State Statistic Service, in 2018, about 140 thousand socially oriented non-profit organizations operated in the Russian Federation, since 2011 their number has increased by 41 thousand, almost half of the country's population -60 million people became recipients of their services in 2018, while the number of services has increased more than 3 times in five years. At the federal level, financial support was provided to socially oriented non-profit organizations in 2018 in the amount of 12.9 billion rubles, the main share of which is distributed in the form of presidential grants -8.0 billion rubles.

However, local rural communities are not yet full participants in local self-government. This conclusion can be made on the basis of the following statistics: in 2019, out of 4,578 non-profit organizations operating in the Samara Region, only 750 or $17 \%$ were registered in rural areas. There is one non - profit organization per 650 citizens, 840 residents in rural areas, and 1,500 if religious organizations are not counted. Rural non-profit organization little active not only in the territory of rural settlements (almost no mention in the media and the Internet on their activities) but also outside: in 2017, the conference of the Samara region from 77 to socially oriented nonprofit organizations, the rural was only 3; 320 Samara participants of competitions Presidential grants 2017-2018 only 5 non - profit organizations- from rural areas.

Social studies have established that Internet users are the most active social group of the rural population with a high level of professional education and innovative culture (Figure 6).

The development of the social capital of rural residents on the basis of modern technological tools is a factor of inclusive development in the new scientific model of rural territories (Figure 7).

IInternet users $\mathbf{\square}$ Do not use the Internet

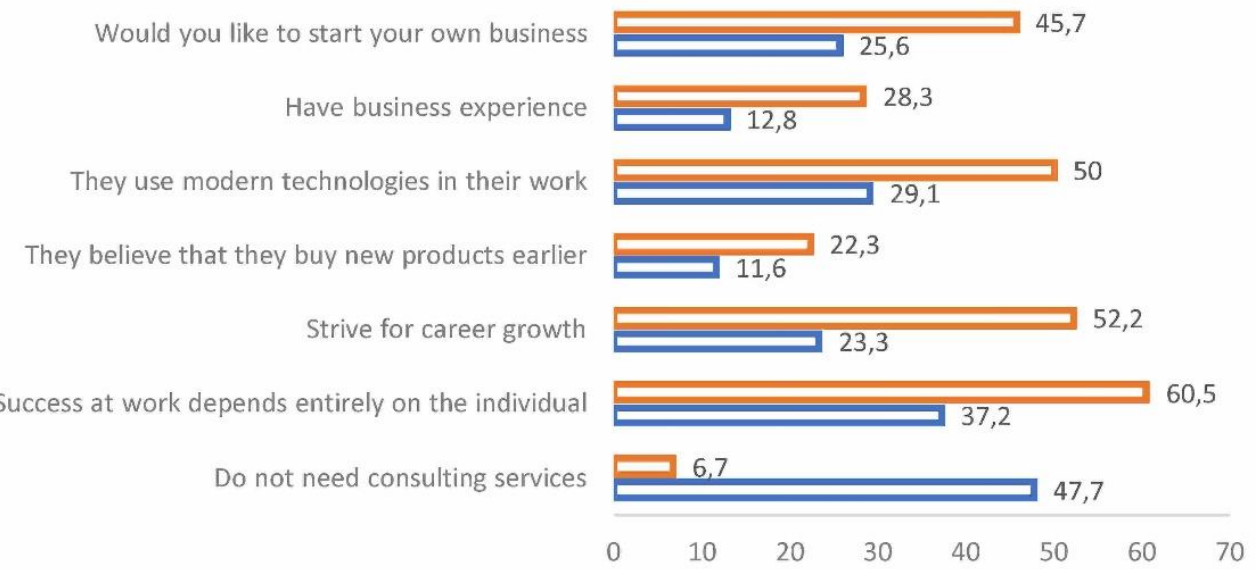

Fig. 6. Social activity of the rural population, $\%$ of the number of respondents in groups. Note: Compiled from the source [26]. 


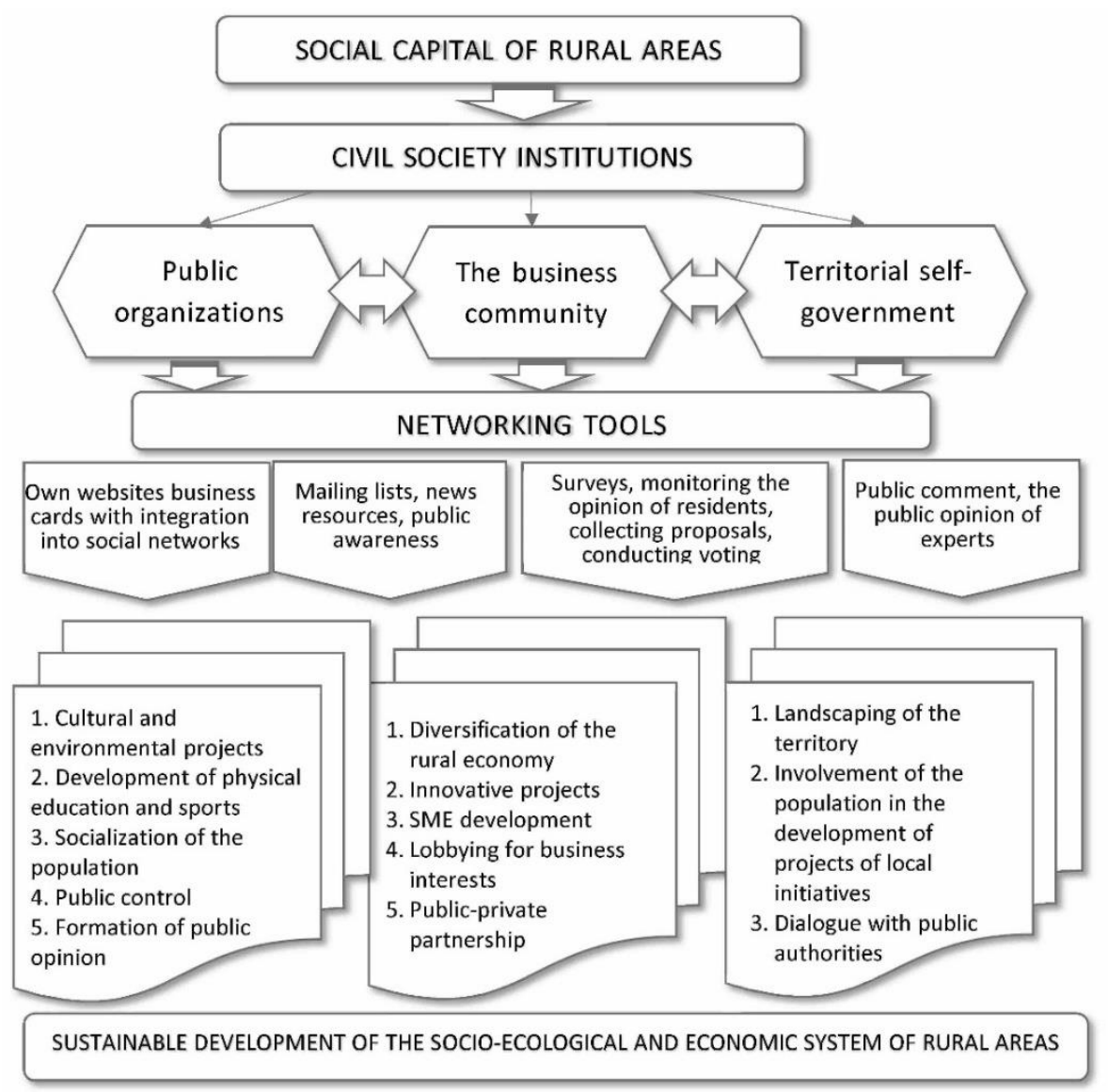

Fig. 7. The mechanism of social capital realization in the new model of rural development. Note: Developed by the authors.

The involvement of the rural population in solving the problems of the territories is taking place today within the framework of the state program "Integrated Development of Rural Territories". A distinctive feature of the program implementation mechanism is proactive budgeting, based on the preparation of development projects with the help of the local population, the project should be in demand, socially significant and receive the approval of most of the villagers.

The main goals of such projects are to improve the social environment for the rural population living in the territory, and to actively involve local resources in the implementation of labor, financial, material and technical resources based on the principles of social partnership.

More fully integrating local resources into the process of rural development, implementing institutional changes, and making extensive use of Web networks can have an incomparably greater economic and social impact than increasing subsidies to a limited number of the same actors [27].

In rural areas of Russia today, there are numerous successful practices of local rural communities, self-organization of villagers with an active civic position is a determinant factor in the development of rural areas. Despite the spatial heterogeneity and disunity of rural areas, modern communication technologies contribute to the formation and 
development of self-organization of the rural population and increase its activity in solving social problems.

\section{Conclusion}

The current model of rural development in the Russian Federation can be identified as an exogenous industry model with all its inherent features and characteristics. It does not properly use human resources, does not form social capital at the local level, which is the basis for the development of rural areas in the XXI century.

The preservation of this model in the future leads to a deterioration of the situation in rural areas of the country. In this regard, it is necessary to move to a territorial model of rural development of a neo-endogenous type based on the principles of inclusiveness.

Earlier studies conducted by the authors showed that the vast majority of the rural population is characterized by a low level of consolidation and self-organization [28]. The financial dependence of local rural communities on the budgets of the regional and federal levels undermines their autonomy, leads to the dominance of the power vertical, turning local self-government into the state administration of localities.

The new model should be based on the following principles: the formation and multiplication of social capital and its basis - human capital, the creation of nongovernmental organizations and rural "networks", effective state support for local initiatives, the spread of various forms of diversified activities in the territories of rural residents, etc. [7].

The concept of "social networks" is becoming a new category of the culture of social interaction with a great prospect for its development.

\section{References}

1. D.J. Snower, Toward Global Paradigm Change: Beyond the Crisis of the Liberal World Order (2018) https://t20japan.org/policy-brief-toward-global-paradigm-change/

2. Goals to Transform Our World, https://www.un.org/sustainabledevelopment/

3. L. Sullivan, L. Ryser, G. Halseth, Journal of Rural and Community Development 9, 219-245 (2014)

4. E. Guinjoan, A. Badia, A.F. Tulla, Boletín de la Asociación de Geógrafos Españoles 71, 495-500 (2016)

5. B. Nilsson, A.S. Lundgren, Eur. Urban Reg. Stud. (2016) http://dx.doi.org/10.1177/0969776416679216

6. E. Pisani, S. Micheletti, Journal of Rural Studies 80, 101-122 (2020)

7. A. Kostyaev, Economics of Agriculture of Russia 10, 88-103 (2018) doi: $10.32651 / 2070-0288-2018-10-88-103$

8. New Rural Policy: Linking up for growth. Background Document, National Prosperity through Modern Rural Policy Conference (OECD, Memphis, USA, 2015)

9. O.V. Nechiporenko, Vestn. Novosib. State University. Series: Philosophy 12(3), 105111 (2014)

10. O.V. Nechiporenko, S. Šljukić, Vestn. Novosib. State University. Series: Philosophy 12(4), 69-77 (2014)

11. Y. Li, X. Wang, H. Westlund, Growth and change 46(1), 133-149 (2015)

12. T. Kramin, R. Grigoriev, A. Timiryasova, et al., Actual Problems of Economics and Law 4(10), 66-76 (2016) 
13. G. Brazhnik, Modern Problems of Science and Education 2, 1-6 (2013)

14. A. Shakirova, T. Kramin, Science Vector of Togliatti State University. Series: Economics and Management 1, 63-68 (2017)

15. S. Akram, J.K. Routray, International Journal of Social Economics 40(9), 760-776 (2013)

16. M. Bułkowska, K. Chmurzyńska, Proceedings of The International Scientific Conference: Rural Development 5(1), 84-91 (2011)

17. T. Guzhavina, Problems of Territory's Development 4(96), 136-152. (2018) DOI: 10.15838/ptd.2018.4.96.9

18. B. King, S. Fielke, K. Bayne, L. Klerkx, R. Nettle, Journal of Rural Studies 68, 123134 (2019) https://doi.org/10.1016/j.jrurstud.2019.02.003

19. Yu.V. Ukhanova, I.V. Paranicheva, Problems of Territory's Development 4(102), 132147 (2019) DOI: 10.15838/ptd.2019.4.102.8

20. A.N. Tarasov, N. Antonova, A.S. Tarasov, G. Bakhmatova, E. Markina, Development of rural territories on the basis of rural economy diversification: state, trends, theories and mechanisms («AzovPrint» Publishing House, 2018)

21. S. Tiwari, M. Lane, K. Alam, Journal of Rural Studies 66, 1-10 (2019)

22. A.S. Lundgren, A. Johansson, Journal of Rural Studies 51, 73-82 (2017)

23. T. Guzhavina, T. Silina, Problems of Territory's Development 6(86), 147-166 (2016)

24. Extended review of the development of digitalization of agriculture in the Russian Federation. Status and prospects (2020) http://www.agrardialog.ru

25. Towards Shared International Standards for Community Development Practice (International Associatio for Community Development (IACD), 2019)

26. M. Morekhanova, Agro-industrial complex: state, trends, prospects (Nikonovskie readings): proceedings of the XVII International Scientific and Practical Conf. 17, 173-175 (2012)

27. A. Kostyaev, Agricultural Science Euro-North-East 21(4), $462-474$ (2020) DOI: https://doi.org/10.30766/2072-9081.2020.21.4.462-474

28. A.N. Tarasov, A.S. Tarasov, N. Antonova, S. Podgorskaya, et al., Institutes and models in the management system of integrated rural development («AzovPrint» Publishing House, 2020) 